\author{
A.B. Nurkamytova ${ }^{1}$, A.Islam ${ }^{2}$ \\ ${ }^{1}$ Suleyman Demirel University, \\ Kaskelen, Kazakhstan \\ ${ }^{2}$ Kazakh Ablai khan University of International Relations and World Languages, \\ Almaty, Kazakhstan
}

\title{
COMPETENCE BASED APPROACH AND KEY COMPETENCIES IN THE MODERN FOREIGN LANGUAGE EDUCATION
}

Abstract

The modern era of educational development faces large-scale problems that are emerging in society. This fact affects the state of education, which cannot at the moment be limited to the transmission of sociocultural norms. The current education system needs to develop the individual's capacity to find and fill socio-economic and socio-psychological niches. This ability can enable individuals to successfully realize themselves, be ready to cater for the demands based on positive communication and the principle of social responsibility. The competence based approach is proved to be an effective solution to all the abovementioned issues.

The article considers the competence based approach in modern education, the definitions of competence based approach, competences and competencies presented by foreign, Russian and domestic scientists. Classifications of key competences put forward by various scholars in the field of education are also described.

Keywords: competence based approach, definitions, competences and competencies, key competencies, modern foreign language education.

\author{
А.Б. Нуркамытова ${ }^{1}$, А. Ислам ${ }^{2}$ \\ ${ }^{1}$ Сулейман Демирел Университеті, \\ Қаскелен қ., Қазақ̆стан \\ ${ }^{2}$ Абылай хан атындавы ҚазХҚ және ӘТУ, \\ Алматы қ.., Қазақ̧стан
}

\section{ҚҰЗЫРЕТТІЛІККЕ НЕГІЗДЕЛГЕН ТӘСІЛ ЖӘНЕ ЗАМАНАУИ ШЕТ ТІЛІ БІЛІМДЕГІ НЕГІЗГІ КҰЗЫРЕТТЕР}

\section{Ан̆датпа}

Білім беру жүйесін дамытудың қазіргі дәуірі қоғамда пайда болатын ауқымды қиындықтарға тап болып отыр. Бұл факт қазіргі білім беру жағдайына кері әсерін тигізеді. Қазіргі білім беру жүйесі жеке тұлғаның, позитивті қарым-қатынас пен әлеуметтік жауапкершілік қағидаларына негізделген икемді жүйеге қабілетті бола алатын, әлеуметтік-экономикалық және әлеуметтік-психологиялық тауашаларды табуға және толтыруға қабілеттілігін қалыптастыру қажет.

Бұл мақалада заманауи білім берудегі құзыреттілікке негізделген тәсіл, шетелдік, ресейлік және отандық ғалымдар ұсынған құзыреттілікке негізделген көзқарас, құзыреттілік пен құзыреттер қарастырылған. Сонымен қатар білім беру саласындағы әртүрлі ғалымдар ұсынған негізгі құзыреттердің классификациялары сипатталған.

Түйін сөздер: құзыреттілікке негізделген тәсіл, анықтамалар, құзыреттер мен құзыреттіліктер, негізгі құзыреттер, заманауи шет тілі білімі. 


\author{
А.Б.Нуркамытова ${ }^{1}$ А.Ислам ${ }^{2}$ \\ ${ }^{1}$ Сулейман Демирель Университет \\ 2. Каскелен, Казахстан \\ ${ }^{2}$ КазУМОиМЯ им. Абылай хана, \\ 2. Алматы, Казахстан
}

\title{
КОМПЕТЕНТНОСТНЫЙ ПОДХОД И КЛЮЧЕВЫЕ КОМПЕТЕНЦИИ В СОВРЕМЕННОМ ИНОЯЗЫЧНОМ ОБРАЗОВАНИИ
}

\begin{abstract}
Аннотащия
Современная эра развития образования сталкивается с масштабными проблемами, которые появляются в обществе. Данный факт отражается на состоянии сферы образования, которое не может на данный момент ограничиваться лишь передачей социо-культурных норм. Нынешней системе образования необходимо формировать у индивида умения найти и заполнить такие социальноэкономические и социально-психологические ниши, которые могли бы позволить личности успешно самореализоваться, быть способной к гибкой системе спросов на основе позитивной коммуникации и принципа социальной ответственности. Компетентностный подход имеет эффективное решение для всех вышеперечисленных задач.
\end{abstract}

Даная статья рассматривает компетентностный подход в современном образовании, опеределения компетентностного подхода, компетенций и компетентности, представленные зарубежными, российскими и отечественными учеными. Также описываются классификации ключевых компетенций, выдвигаемые различными учеными в сфере образования.

Ключевые слова: компетентностный подход, определение компетенций и компетентности, классификация ключевых компетенций, современное иноязычное образование.

Introduction. The official introduction of the concept of competence into learning dates from the mid1960s in the United States, although the theoretical foundations of a competency approach were laid in the early 20th century. [1, p. 67] Beginning in the 1970s, the first experiments were conducted with competency reforms in higher education (Grant, 1979). During the same period Zemke (1982) presented the work on improvement of training design by means of the competences demanded in workplaces. The works of western authors such as Burke (1989), Fletcher (1991), Blank (1992) .highlighted improvement in society, education, learning thanks to a competence approach [2, p. 53].

Methodology. The main method of the article under consideration is the method of descriptive analysis. Scientific works of foreign, Russian and Kazakhstani scholars on the given topic have been thoroughly examined and analyzed in order to extract their main ideas and include them in this article.

The concept of "competence" concerning the theory of language in general application was put forward by N. Chomsky in 1965 where he draws a fundamental distinction between competence (knowledge of own language by a speaker and a listener) and performance (real use of language in specific situations) [3, p. 34]. The understanding of the differences between the terms "competence" and "competency" existed in the 1960 s, but there is still no clear interpretation of these definitions. O.A. Salnikova made the analysis of dictionary entries and found three approaches to their definition: "1) absence of the concept of "competence"; 2) their definitions are synonymous; 3) defining competence as a distracted noun to the adjective "competent". At the same time, both concepts are used in official documents [4, p. 75].

In recent decades in the works of scientists studying the topic of competence approach in foreign language education there has not been general understanding of the basic concepts of "competence" and "competency".

O.A. Ulyanina argues that "to date there are two fundamentally different options for interpreting the concepts of "competence" and "competency":

1) equation of concepts competence/competency (they are interchangeable and complementary);

2) differentiation of concepts where competence is a more global comprehensive characteristic of the individual, and competencies are structural components of competence in general" [5, p. 139].

Scientists who base their works on the first version of interpretation of concepts (L.N. Bolotov, V.S. Lednev, N.D. Nikandrov, M.V. Ryzhakov, V. Serikov) argue that competence is the ability to effectively carry out any work activity and meet the requirements set for a particular profession. The term competency 
has the same meaning, but is used in descriptive terms. Practice-oriented direction is monitored in competences [5, p. 139]. Thus, competence acts as a bridge between knowledge and certain actions, and the competence based approach is the realization of the practical orientation of foreign language education.

Representatives of the second variant (I.A. Zymnaya, A.V. Khutorskoy) distinguish between the concepts of competence and competency, characterizing the latter as primary [6.7]. Scientists relating to the second option have gained the greatest recognition among scientists and practitioners in the distinction between the concepts of competence and competency.

A.V. Khutorskoy: "We will try to separate these concepts, having in mind by "competency" slightly alienated, previously specified requirement to educational training of a student, and by "competence" a student's already developed personal quality (characteristic)" [7, p. 24].

I.A. Zymnaya: "Competencies are some internal, potential, hidden psychological newly formed structures: knowledge, representations, programs (algorithms) of actions, value systems and relations, which are then revealed in human competencies" [6, p. 9].

G.A. Sergeyev: "Competency is understood as a set of interconnected qualities of a person, set in relation to a certain range of objects or processes and necessary to act qualitatively and productively in relation to them. Competence is defined as a person 's possession of an appropriate competence, including his personal attitude towards her and the subject matter of the activity. Thus, competences act as goals of the educational process, and competence - as a result, a set of personal qualities of the specialist "[8, p. 12].

E.O. Ivanova: "Competency is a set of traditional knowledge, skills and capacities with personal features of a schoolboy, with his self-consciousness, reflection in the process of cognitive activity... We understand competence as possession of the corresponding competency, i.e. set of the interconnected knowledge, abilities, skills and the relations connected with a subject of study allowing to carry out purposeful and effective actions with it "[9, p. 19].

I.S. Sergeyev, V.I. Blinov: "Competence is readiness to perform certain functions, and the competence based approach in education is nothing but the target orientation of the educational process on the formation of certain competencies" [10, p. 23]. "Competency - human readiness to mobilize knowledge, skills and external resources for effective activity in a specific life situation... readiness to act in a situation of uncertainty "[10, p. 23].

As we can see, the concept of "competency" is based on knowledge, skills, experience and personal qualities. The basic idea of the competence based approach is that all knowledge gained should be applied in practice. All knowledge of a theoretical nature should become a tool for solving practical problems. The aim of education should be not to raise awareness of students, but to support self-help in solving problems in different situations.

Competencies include internal motivation of the individual, emotional attitude to the activity. Personal qualities included in the competencies are gathered into groups [9, p. 20]:

1) cognitive (informative) qualities - ability to ask questions, to find the reasons of the phenomena, to express misunderstanding of a question, etc.;

2) creative (creative) qualities - inspiration, imagination and keenness to contradictions, freedom of thoughts and feelings, criticality, existence of own opinion, etc.;

3) organizational (methodological) qualities - ability to study, ability to set and achieve a goal; reflexive thinking and self-esteem, etc.;

4) communication qualities, which are necessary to interact with other people, objects of the world and information, performance of various social roles in the group and collective, use of telecommunication technologies (e-mail, Internet);

5) worldview qualities, which determine emotional-value characteristics of a student, his ability to selfknowledge and self-movement; Ability to find their place in the surrounding world, family, work; national and universal human aspirations, patriotic qualities of personality, etc. [8, p. 13].

The existence of the above-mentioned qualities allows to consciously use, complement, improve existing knowledge, to direct them to solutions of emerging problems.

So competency is the accumulation of knowledge, skills and experience in a certain field of activity and the individual's understanding of the value of this activity. Competence is the possession of a certain competency, as well as a characteristic of a person regarding the effectiveness of his or her activities.

There are different types of competencies that can be classified by their levels and types. Scientists group competencies based on their theories and on the purpose of their research. Basically, competencies vary as key and professional. 
Key competencies are "the most general (universal) abilities and skills that allow a person to understand the situation and achieve results in personal and professional life in conditions of increasing dynamism of modern society" [11, p. 14]. Key competences are universal mental remedies, ways, methods and techniques of achievement of the purposes, significant for the personality. They are out-of-order and are perceived as the basis of human life. Therefore, each member of society must master key competencies to acquire functional literacy.

The Council of Europe has identified 5 key competencies that young Europeans "should be equipped with" [11, p. 14]:

1. Political and social competencies - the ability to take responsibility, participate in group decisionmaking, resolve conflicts non-violently, participate in the maintenance and improvement of democratic institutions.

2. Competencies related to life in a multicultural society, or intercultural competences, tolerance, acceptance of differences between people, respect for others, ability to live with representatives of other cultures, languages and religions.

3. Competencies relating to the possession of oral and written communication, which is particularly important for work and social life, with the emphasis that people who do not possess them are threatened by social exclusion (in the same context, ownership becomes more important than one language).

4. Competencies related to increasing an amount of information in a society -knowledge of information technologies, understanding of their application.

5. The ability to learn throughout life as a basis for continuous learning in the context of both personal professional and social life.

Professional competencies are also classified by different authors according to the purposes of their research. For example, Katz and Kahn 1986 grouped competencies into three categories, which were further deployed to 4 categories: 1) Technical or functional (knowledge, attitude, skills, etc., relating to the technology or functional assessment required to perform a particular role); 2) Management (knowledge, relationships, skills, etc., required for planning, organization, mobilization and disposal of various resources); 3) Human (knowledge, relationships and skills, etc., Necessary to motivate and develop human resources); and 4) Conceptual category (ability to visualize the invisible, think at abstract levels, and use thinking to plan a potential business). [12, p.20]

"Along with Western, there are a variety of Russian classifications, which include value-sense, general, cultural, educational and cognitive, information, communicative, social and labour competences and competence of personal self-improvement." [4, p.76] The most convincing classification, according to O.A. Salnikova, is presented in the works of A.V. Khutorskoy and his followers:

1. Means of worldview orientation (value-sense competency);

2. Knowledge and skills in a certain sphere (educational and cognitive, informational, communicative, social and labour competencies);

3. The range of issues one has to be aware of (general cultural competency);

4. Basis for mastering the methods of physical, spiritual and intellectual self-development (competency of personal self-improvement).

It should be noted that educational competences are differentiated by A.V. Khutorskoy according to the same levels as the content of foreign language education:

- Key (implemented on common content for all subjects);

General (implemented at the interdisciplinary level in the educational sphere);

- Subject (implemented within individual subjects).

O.A.Salnikova identifies the general characteristic of key competences, the content of which includes:

- Social and personal significance, conceptual value of competency;

- Its practical condition;

- Minimum practical experience; levels of mastering competencies. [4, p. 76]

The list of key competences depends on the values that are important at a certain stage of society development. However, it is possible to identify the bulk of key competencies, which are less dependent on any social change and are aimed at the long term. This mass will necessarily include communicative competence, without which human socialization is impossible. It follows that one of the tasks of modern education is the formation of communicative competency of students throughout all years of education and the means of all educational subjects. 
Communicative competence, its main characteristic and classification developed by various scientists, including Kazakhstani scientist S.S. Kunanbayeva will be considered by us in our further scientific study.

Conclusion The analysis of different approaches to the definition of competences and competencies, as well as their classifications, has led to several conclusions:

1) Despite the fact that the competence based approach and concepts of competence and competency appeared in the 1960-1970 "s, there is no single clear formulation of the definitions of these terms at the moment.

2) In the works of foreign authors studied by us, there are more classifications of professional competencies than classifications of the key competencies.

3) During the study of the sources used in this article, it was revealed that the classification of A.V. Khutorskoy today is the basis for further study of competencies by various authors.

\section{References:}

1. Richard J. Mc Cowan. Origins of Competency Based Training. SUNY Research Foundation/Center for Development of Human Services, 1998.

2. Weigel, T.,M. Mulder \&Collins The concept of competence in the development of vocational education and training in selected EU member states. Journal of Vocational Education and Training, ,59, 1, 2007, 51-64

3. Тесленко, В.И. Коммуникативная компетентность: формирование, развитие, оценивание / В.И. Тесленко, С.В. Латынцев. - Красноярск: Изд-во Красноярского гос. пед. ун-та, 2007.

4. Сальникова О.А., Ключевые компетенщии в современном образовании // Начальная школа плюс До и После, 2011, № 12. - С. $74-78$.

5. Ульянина О.А. Компетентностный подход в научной парадигме российского образования Психолого-педагогические исследования 2018. Том 10. № 2. С. 135-147.

6. Зимняя, И.А. Ключевые компетенции - новая парадигма результата образования /И.А. Зимняя // Эйдос: Интернет_журнал. -2006. -[Электронный ресурс]. - http://www.eidos.ru

7. Хуторской, А.В. Общепредметное содержание образовательных стандартов / А.В. Хуторской. - М.: Ин-т новых образовательных технологий, 2002.

8. Сергеев, Г.А. Компетентность и компетенции в образовании / Г.А. Сергеев. - Владимир: Издво Владимирского гос. ун-та, 2010.

9. Иванова, Е.О. Компетентностный подход в соотномении со знаниево-ориентированным и культурологическим / Е.О. Иванова // Эйдос: Интернет_журнал. - 2007. - [Электронный ресурс]. http://www.eidos.ru

10. Сергеев, И.С. Как реализовать компетентностный подход на уроке и во внеурочной деятельности / И.С. Сергеев, В.И. Блинов. - М.: АРКТИ, 2007.

11. Иванов, Д.А. Компетентности и компетентностный подход в современном образовании / Д.А. Иванов. - М.: Чистые пруды, 2007.

12. Katz Daniel and Kahn Robert The Social Psychology of Organizations. John Wiley \& Sons, New York, 1966. 